\title{
School Management from the Voice of Their Protagonists in Spain
}

La dirección de centros escolares desde la voz de sus protagonistas en España

A gestão escolar pela voz de seus protagonistas na Espanha

Rosario Ordóñez-Sierra* (ID orcid.org/0000-0002-8563-9975 Margarita Rodríguez-Gallego** (iD) orcid.org/0000-0001-6959-4829 Antonia López-Martínez ${ }^{* * *}$ (D) orcid.org/0000-0003-3460-9546

\footnotetext{
Para citar este artículo: Ordoñez-Sierra, R., Rodríguez-Gallego, M. y López Martínez, A. (2020). School Management from the Voice of Their Protagonists in Spain. Revista Colombiana de Educación, 1(79), 301-324. https://doi.org/10.17227/rce.num78-8370
}

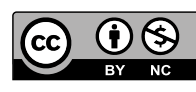

Recibido: 05/09/2018

Evaluado: 03/09/2019 


\begin{abstract}
This study gathers the contributions of school principals' professional skills, their access to the role as heads and the main advantages and disadvantages of being a school principal. The study involved 20 principals from the province of Seville. A qualitative methodology was used, through semi-structured interviews and content analysis. From the analysis of the results, specific aspects are deduced in the categories studied such as: access to the principal position, competencies, advantages, difficulties, management model. Most of the principals interviewed assured that accessing the position is assumed with willingness to face challenges, and that management competencies, capacity to listen and empathy are essential for the role. Their work is facilitated by their relationships with their co-workers and a good management team, followed by the support of the educational community. On the other hand, they stated that their duties are hindered mainly by families who are not involved and discipline issues.
\end{abstract}

\section{Keywords}

school management; competencies; management model; leadership; Early Childhood and Primary Education centres

\section{Palabras clave}

dirección escolar; competencias; modelo directivo; liderazgo; centros de educación infantil y primaria

\section{Resumen}

El estudio recoge las aportaciones de los directivos escolares sobre sus competencias, acceso al cargo y, aquellos factores que facilitan y dificultan la dirección del centro. En el estudio participaron 20 directores/as de la provincia de Sevilla. Se utilizó una metodología cualitativa, a través de entrevistas semiestructuradas y análisis de contenido. Del análisis de los resultados se deducen consecuencias en las categorías estudiadas como son: acceso al cargo de dirección, competencias, retos, dificultades y modelo directivo. La mayoría de los directivos entrevistados manifiestan que el acceso al cargo de la dirección es asumido para enfrentar retos, siendo esencial las competencias de gestor, la capacidad de escucha y la empatía, entre otras. Su trabajo es facilitado por las relaciones con sus compañeros/as, un buen equipo directivo, el respaldo de la comunidad educativa y la comunicación. Por el contrario, sus deberes son obstaculizados por las familias que no se involucran y los problemas de disciplina.

\section{Resumo}

O estudo reúne as contribuições dos diretores das escolas sobre suas competências, acesso ao cargo e fatores que facilitam e dificultam a gestão do centro. Vinte diretores da província de Sevilha participaram do estudo. Utilizou-se uma metodologia qualitativa, por meio de entrevistas semiestruturadas e análise de conteúdo. A partir da análise dos resultados, são deduzidas conseqüências nas categorias estudadas, tais como: acesso ao cargo de gerência, competências, desafios, dificuldades e modelo de gestão. A maioria dos gestores entrevistados afirmou que o acesso à posição gerencial é assumido para enfrentar desafios, sendo essenciais habilidades gerenciais, habilidades de escuta e empatia, entre outros. Seu trabalho é facilitado pelo relacionamento com seus colegas, uma boa equipe de gerenciamento, o apoio da comunidade educacional e a comunicação. Pelo contrário, seus deveres são dificultados por famílias que não estão envolvidas e os problemas disciplinares.

\section{Palavras-chave}

gestão escolar; competências; modelo de gestão; liderança; centros de educação infantil e primária 


\section{Introduction}

The present study gathers the contributions of school principals about perceived competencies for the performance of their duty and the factors that facilitate or hinder day-to-day work in the educational centre, with the aim of determining the problems they face and their direct impact in practice.

In Spain, since the Organic Law of the Right to Education (LODE, 1985) came into force, an important modification took place in the model of access to school management, turning from being done through appointment by the ministry to election by the educational community, which began to allow most of the teaching staff of the centre to stand as a candidate for election.

Nowadays, those who become school principals are teachers elected by a commission of representatives of the administration and, also, by their own colleagues. After a period of four or eight years, they resume their role as teachers. During their term of office, the managerial responsibilities gathered in the established text of the LOE-LOMCE (2016) (art. 132C) are: "to perform the pedagogical management, to foster educational innovation and to promote plans that lead to the achievement of the centre's educational project goals". It seems that, apart from being a manager and representing his/her co-workers, this law states that the principal must also perform a good pedagogical duty. However, this management model, in Spain, rather than democratic, has been configured as collegial, which has severe consequences for the day-to-day performance of the pedagogical role. The principal becomes a prisoner of his/her colleagues' demands, and this poses serious obstacles to pedagogically "move" the educational centre toward a progressive improvement of teaching. Unless those who perform the principal role earn a moral authority, the institution labels them with a weak identity, given their "parity" with the teachers (Ritacco \& Bolivar, 2016).

In addition to the above mentioned, the following changes are stated in the established text of the LOE-LOMCE (2016), which refer to the requirements to stand as a candidate to be elected principal and to participate in the competition on the merits:

To possess accredited certification of completion of a training course on the performance of the principal role, provided by the Ministry of Education, Culture and Sports or by the educational administrations of the Autonomous Communities. The characteristics of the training course will be regulated by the government. The certifications will be valid in the whole of the national territory. (Art. 134). 
This model of school management, unlike the international tendencies, is more focused on the bureaucratic and administrative aspects and, according to some authors (Bolívar, 2010a; Ritacco \& Bolívar, 2016; Gago, 2006), it has proven to be insufficient for the development of pedagogical conditions that favour the learning of students in each of the classrooms. In fact, Bolívar (2015) stated that now the LOMCE proposes to go back to old practice, by which the school principal must be the delegate of the administration and make sure that the centre complies with the regulations, whereas in the most advanced countries in this matter the principal has a more professional role of pedagogical leadership. Different studies about the professionalization of the school principalship show the distance between legislation and the actual capability of principals to perform certain duties, such as pedagogical leadership and coordination, innovation and interaction with the community (Ainscow \& West, 2008; Barrios, Iranzo \& Tierno, 2013; Iranzo, Barrios \& Tierno, 2008).

Therefore, school principals find many difficulties in practice to improve teaching, considering that school management in Spain has moved among the following roles: representative-delegate of the administration (central or regional), manager and enforcer of the compliance with the regulations, and delegate of the faculty (Bolívar, 2010a; Viñao, 2016; Perines \& Hidalgo, 2018).

The training that principals receive during their term of office is a fragmented, legalistic training that has no references to the context of each centre (Bernal, 2008). To respond to the formative deficiencies, special emphasis must be placed on the demands that arise from the educational practice (Vázquez, Liesa \& Bernal, 2015; Izquierdo, 2016).

Estruch (2002) highlighted three management models within the European framework: 1) the bureau-professional management model, based fundamentally on the representation of the centre's administration; it is applied in countries with more centralistic educational systems, such as Belgium, France, Greece or Italy. 2) The pedagogical-professional management model, focused on the improvement of the quality level and the school and social context, in which the leadership functions are a priority; it is applied in countries with more decentralised educational systems, such as those in Northern Europe. And the bureau-participative management model, which is between the first two models. The principal is democratically elected by the community, but appointed by the administration, as is the case of Portugal or Spain.

There is not a single improvement project without a good management team behind it, even if the latter is not the direct protagonist. Therefore, the capacity to improve a school depends, in a relevant manner, on management teams with pedagogical leadership, resource management 
leadership and administrative leadership (INEE, 2013) that actively help invigorate, support and encourage its development, in order for the school to build its own improvement potential (Bolívar, 2010b; Day et al., 2011). In the last few years, there has been an increasing number of studies on the strategic aspect of school leadership in the improvement processes (Hallinger \& Heck, 2011; Leithwood, Patten \& Jantzi, 2010). Leadership plays a relevant role in the international educational policies of the OECD member countries (Heck \& Hallinger, 2010; Pont, Nusche \& Moorman, 2009) and it is considered the second most decisive and influential factor of school grades, after the teacher's performance in the classroom (Bolívar, 2010b; Gairín \& Castro, 2010; Informe McKinsey, 2010).

Nowadays, it has been reported that leadership is influenced by the characteristics of the environment of the schools, and that it is a social phenomenon (Hallinger \& Heck, 2011; Mulford \& Silins, 2009; Sánchez-Moreno \& Hernández, 2014) determined by the relationships between the leader and his/her followers, the characteristics of the school project and the educational and social context of each school.

Taking as a reference several previous studies on the competencies of school management (Álvarez, 2006; Caminero, 2012; García \& Poblete, 2003; Pont \& Teixidó, 2002; Teixidó, 2007), these can be summarised into the following: planning and development of strategies, individual and team decision making, interpersonal relationships, emotional control, leadership, negotiating, adjusting activities to previous regulatory procedures, adapting to context, problem solving, innovation project making, entrepreneurial spirit, ethical behaviour, motivating and encouraging the staff, permanent education and self-assessing their organization. To sum up, the school management must be competent in administration, leadership, mediation, education and quality in order to achieve better results.

Therefore, it is important in this study to determine the competencies and difficulties that are perceived as necessary for the development of management.

\section{Methodology}

The present research was based on a qualitative methodology. It is framed within the interpretive paradigm (Hernández, Fernández \& Baptista, 2010). The aim of this study is to determine which competencies and factors facilitate and hinder the managerial duties of the educational centre for the improvement of teaching, with the aid of the perceptions that principals have about their experience. 


\section{Objectives}

The present study aims:

1. To describe the characteristics and challenges that influence their decision to stand as a principal candidate.

2. To analyse the perceived competencies to perform their role.

3. To determine the factors that facilitate and hinder the characteristic tasks of the principalship.

4. To analyse how they define themselves within their management model.

\section{Context and participants}

The study was conducted with school principals from Early Childhood and Primary Education centres (ECPEC) within the city of Seville and its province (Spain). The characteristics of the population, as well as the number of participants in the sample, were not selected in advance, but gradually, throughout the duration of the study, following representativeness and authorization criteria. In this context, the study began with 35 school principals, although after considering the afore mentioned criteria, the sample was reduced to 20, who gave their consent for the interview to be used and published; $70 \%$ of them were male and $30 \%$ female. Ninety percent of them were from public centres located in either urban $(60 \%)$ or rural areas (40\%). Thirty percent of the participants had between 20 and 25 years of experience, $20 \%$ of them had less than 20 years of experience and another $20 \%$ had between 25 and 30 years of experience. Only one participant ( $5 \%$ of the sample), had more than 30 years of experience.

Regarding age, $25 \%$ of the principals were between 41 and 45 years old, another $25 \%$ were between 46 and 50, 20\% were over 56, 15\% between 51 and 55, 10\% between 31 and 35 and $5 \%$ between 51 and 55 .

\section{Information gathering strategies}

Information was gathered by means of semi-structured interviews, which had a flexible script of open questions based on the difficulties that the participants find in their duties to improve teaching. Through these interviews, we selected the information that we considered to be most relevant for the study. This way, we intended to validate the theories about the research problem by focusing on their verification. 


\section{Data analysis}

A content analysis was conducted for each of the interviews using the Atlas. ti 6.2 software. As a result of this process, a system of categories and codes (with their corresponding frequencies) was established. To carry out the qualitative analysis, the categories were selected according to indicators provided by the interviews. In addition to describing and explaining the system, the frequencies of each code were analysed, which allowed establishing the significance of each category.

In order to ensure the validity and reliability of the results obtained, a triangulation of encoders was performed; i.e. the content analysis, based on the system of categories and codes, was applied by three researchers, and the concordance level between them was calculated, using Cohen's Kappa coefficient.

To sum up, this allowed showing the information gathered and presenting the results according to the objectives proposed.

\section{Table 1.}

System of response categories and codes

\begin{tabular}{|c|c|c|}
\hline Items & Category & Code \\
\hline $\begin{array}{l}\text { 1. Why did } \\
\text { you decide } \\
\text { to stand } \\
\text { for school } \\
\text { principal? }\end{array}$ & Access & $\begin{array}{l}\text { ADMl I was proposed by the administration } \\
\text { FACL faculty } \\
\text { CHAL challenge } \\
\text { ASKE I was asked by the former principal or proposed by } \\
\text { colleagues } \\
\text { RETI the former principal retired and i was the head of studies }\end{array}$ \\
\hline $\begin{array}{l}\text { 2. What } \\
\text { competencies } \\
\text { must a } \\
\text { good school } \\
\text { principal } \\
\text { have? }\end{array}$ & $\begin{array}{c}\text { Competen- } \\
\text { cies }\end{array}$ & $\begin{array}{l}\text { AUTH authority } \\
\text { COLL understanding one's colleagues } \\
\text { DELE know how to delegate (distributed leadership - team work) } \\
\text { SPEA Speak } \\
\text { EMPA empathy } \\
\text { ENVI normalised working environment } \\
\text { LIST listening } \\
\text { TRAI training } \\
\text { WORK know how the centre works } \\
\text { MANA management of human resources and materials } \\
\text { SOCI SOcial skills } \\
\text { INNO innovative } \\
\text { MEDI mediator } \\
\text { MOTI motivator } \\
\text { NECO negotiator } \\
\text { REGl know the regulations } \\
\text { ORGA Organised } \\
\text { PATI patience } \\
\text { RIGO rigour }\end{array}$ \\
\hline
\end{tabular}




\begin{tabular}{|c|c|c|}
\hline Items & Category & Code \\
\hline $\begin{array}{l}\text { 3. What } \\
\text { elements } \\
\text { facilitate } \\
\text { your duties } \\
\text { as a school } \\
\text { principal? }\end{array}$ & Advantages & $\begin{array}{l}\text { ADM2 administration } \\
\text { COTE communication with the teachers } \\
\text { EDCO educational community } \\
\text { MATE management team } \\
\text { PARE parents } \\
\text { REG2 regulations } \\
\text { PLAN planning documents } \\
\text { RELA relationships } \\
\text { SUPP SUPport } \\
\text { RSPN responsibility between colleagues }\end{array}$ \\
\hline $\begin{array}{l}\text { 4. What } \\
\text { difficulties } \\
\text { have you had } \\
\text { as a school } \\
\text { principal? }\end{array}$ & Difficulties & $\begin{array}{l}\text { BICE big centre } \\
\text { SICK Sick leaves among teachers } \\
\text { RELl relationship with the students } \\
\text { PARl parents } \\
\text { BURE bureaucracy } \\
\text { REC3 regulations / regulatory changes } \\
\text { TEAC teachers } \\
\text { LAEX lack of experience } \\
\text { StUd students } \\
\text { NEPR new projects }\end{array}$ \\
\hline $\begin{array}{l}\text { 5. How would } \\
\text { you define } \\
\text { your school } \\
\text { management } \\
\text { model? }\end{array}$ & $\begin{array}{c}\text { Management } \\
\text { model }\end{array}$ & $\begin{array}{l}\text { PART participative } \\
\text { REPR representative } \\
\text { MIXE mixed }\end{array}$ \\
\hline
\end{tabular}

Own source

\section{Results}

In this section, the results of the study are presented, taking as a reference the system of response categories and codes (with their corresponding frequencies), which was established after the content analysis had been carried out with the data gathered from the interviews.

In the access category, we were interested in why principals decided to stand as candidates for their current role. One of the most repeated codes was $\mathrm{CHAL}$ (frequency $=7$, i.e. 35 of the participants). They stated that it is an essential premise for a principal candidate to face it as a challenge in which one can innovate and organize the teachers and their students. "[...] On the other hand, I like facing challenges, being able to keep innovating and learning new things every day, and this role allows me to do so. I decided to launch myself into a new adventure and accumulate new experiences". P8: (12:12), CHAL. "[...] It was a personal challenge for me, and it still is today". P18: (14:14), CHAL. 
Their decision, likewise, was determined by the fact that either their colleagues proposed so, or the former principal asked them personally (ASKE, frequency $=7$, i.e. $35 \%$ of the participants):

[...] I was elected principal, even though I didn't stand for the role. However, seeing that my colleagues supported me in a time of transition in which nuns were disappearing from the school management, it was very motivational for me to accept the position. P7: (14:14), ASKE.

Likewise, it must be highlighted that for a large percentage of the sample it was not a decision made by the candidates, but it was the administration $(A D M 1$, frequency $=6$, i.e. $30 \%$ ), specifically the inspector, who proposed them to accept the role.

[...] Basically, it was not my intention. I was appointed by the administration for this position after nine years of service as a primary education counselor in a teachers' centre. I was assigned the tasks to close down the two public centres of the locality, participate in the itemisation and reallocation of their staff and create a new educational centre in town with new facilities and human resources generated from this relocation of the ones that belonged to the two centres that were shut down. P18: (14:14), АDM1.

A lower percentage took the role because the former school principal had retired (RETI, frequency $=4$, i.e. $20 \%$ ),

[...] first, obviously, because the opportunity emerged. The principal retired and someone had to manage the centre. Usually, the role would be assumed by the head of studies, although it is not compulsory. Second, it had to be taken into account that nobody wanted to stand for school principal. And, lastly, because of my personality; I had already been head-of-studies for four years, so I see education from another perspective. P12: (12:12), RETI.

Finally, the smallest percentage of the sample became school principals because their colleagues proposed them to do it, and they had the support of all the teachers ( $\mathrm{FACL}$, frequency=3, i.e. $15 \%$ ):

[...] I decided to stand for principal in my institution for several reasons. One of them, a very important one, is that my faculty believed and still believe in me, and I have felt their support at all times; it was them who motivated me to take this great step. P8: (12:12), FACL.

Regarding the competencies category, the principals interviewed consider that a good principal must have many of them, although they highlighted that a principal must be a good manager of human resources and materials (MANA, frequency=6, i.e. 30\%): "[...] Most important of all, 
a principal must be a pedagogical leader of the centre, and a leader that knows how to manage the human resources and materials of the centre, be it economic...". P10: (24:24), MANA. "[...] People should say this. Basically, the principal must be skilled in management, because it is a position in which you dedicate a lot of time dealing with the administration, the city hall, parents, students, colleagues..., and so it is very different from being only a teacher. Especially, management skills". P14: (19:19), MANA.

A slightly lower percentage highlighted the capacity to listen and support the teachers and parents (LIST, frequency=5, i.e. $25 \%$ ): "[...] A school principal must have similar ideas to fulfil the duties and the work of that team. He/she must listen to all the teachers to try and solve all the problems that may arise". P6: (21:21), LIST.

A lower percentage of the sample highlight the following competencies as equally important: authority, know how to delegate, dialogue, empathise, know how the centre works and motivate (AUTH, DELE, SPEA, EMPA, WORK and MOTI, frequency=4, i.e. $20 \%$ ). As was previously mentioned, authority, when making decisions, is fundamental:

[...] It is also important to keep calm when making decisions. I have no problem with making decisions. However, I first take my time to think about them and then I always discuss some of them with the management team and others with my colleagues. P12: (19:19), AUTH.

A school principal must be able to delegate, since education is considered a public service in which all the sectors of the community have the right to participate:

[...] It is also essential to have the capacity to delegate. There are so many aspects to be considered for the performance of the daily duties that these would be impossible to achieve without the participation of the work teams and without assuming their management, focusing their efforts on the aspects in which they are competent". P18: (19:19), DELE.

Among the social capacities required, it stands out: to be able to speak with the educational community (SPEA), to be able to perceive the problems of teachers, parents and students, and being able to be and act as a colleague (EMPA), to perfectly understand how the centre and its facilities work (WORK), andto be able to motivate the co-workers (МОтI) in order to achieve the goals and objectives proposed and improve the academic performance of the students:

[...] the willingness to work and the eagerness to share this enthusiasm with others should always be there. A united, motivated and enthusiastic faculty turned an ordinary centre into a special and happy centre, in which our students feel comfortable, supported and eager to work. P8: (15:15), мОтІ. 
Among other characteristics, the participants highlighted the following: understanding one's colleagues, developing all kinds of social skills, and being innovative, organised and patient (COLL, SOCI, INNO, ORGA and PATI; frequency $=3$, i.e. $15 \%$ of the sample).

[...] Leadership skills and the capacity to promote team work, motivate colleagues, manage information and decision making, communication skills, the capacity to resolve conflicts and promote coexistence, managing, organising and coordinating a centre, strategic management, control and supervision skills, and change and innovation management. P3: (16:16), soCI.

Likewise, they proposed that one of the hallmarks of a principal must be his/her commitment with educational innovation: "[...] I also think it's important for a principal to be eager to innovate and include improvements in the centre and improvements that favour the students". P17: (19:19), INNO. A principal's organisation capacity is also highlighted:

[...] There are many documents generated in paper, computer files... a disorganised person does not make it any easier. Therefore, if I do not know where my stuff is, any problem or query can escalate. So, a principal must be organised, and not only with paperwork, but everything. P12: (18:18), ORGA.

In addition, the participants stated that a principal must have great patience and fair judgement to solve the problems that arise throughout the day:

[...] Even though they had a bad night, they must come to the centre with a smile in their faces; moreover, they must be very patient with the children, the parents, the teachers, 'why did I get this schedule', 'why do I have to substitute', 'why can't somebody else fill in for me' $[. .$.$] .$ P9: (21:21), PATI.

Mediation is one of the key features of a principal, who must intervene in the daily conflicts that arise from coexistence and converge in the everyday reality of the educational centre, especially in the relationships between the staff and the parents and relatives of the students (MEDI, frequency $=2$, i.e. $10 \%$ of the sample). The participants also pointed out that a principal must be able to negotiate and know the regulations very well, since the centre must always comply with them (NEGO, REG1: frequency $=2$, i.e. $10 \%$ of the sample). Lastly, other characteristics were indicated, such as rigour, legislative training, responsibility, strictness, leadership, prevision, eagerness to work, knowledge and understanding of the needs of teachers, students and the environment, etc. 
With respect to the advantages category, which corresponds to the benefits that principals find in their institution for the performance of their duties, the participants highlighted the relationships with their colleagues (RELA, frequency $=7$, i.e. $35 \%$ of the sample). It is very important to have a good team of teachers supporting you and facilitating communication for you, and that such involvement allows relationships to be fluid:

[...] As well as the daily interaction with the rest of the teachers, since I see everyone every day, which facilitates communication a lot. Furthermore, I trust them fully and I feel that they also trust me, and that really makes my duty easier. P1: (17:17), RELA.

Likewise, another third of the principals interviewed pointed out that having a good management team is key, since these are people who work with you every day to achieve the goals set (MATE, frequency $=7$, i.e. $35 \%$ of the sample): "[...] and, of course, the fact that my management team works at $100 \%$. We understand each other very well and we love to work together. All three of us are passionate about our work". P8: (18:18), MATE. A slightly lower percentage of the participants stated that support is essential, since it makes everything easier (supp, frequency $=6$, i.e. $30 \%$ of the sample). Communication with the teachers is also fundamental (COTE, frequency $=4$, i.e. $20 \%$ of the sample), especially with those a school principal trusts for the accomplishment of the duties: "[...] whom one can talk to about every issue, without feeling awkward due to a lack of confidence or not knowing how to tackle the problem". P14: (22:22), сОтЕ.

Among the advantages that facilitate the performance of their duties, the participants highlighted the following with the same frequency: administration, educational community, responsibility between co-workers and planning documents (ADM2, EDCO, RSPN and PLAN, frequency=3, i.e. $15 \%$ of the sample). The principals benefit from the administration, which helps them with the provision of human resources and materials, from the good relationship between all the people involved in the centre (families, children, administration staff and public employees), from the responsibilities that their colleagues assume for the realization of the activities and from good planning strategies: "[...] well, first of all, the support of the administration and their contribution regarding resources, both materials". P4: (17:17), ADM2. "[...] also the meetings with the relatives of the students and the good relationship that we maintain between all the people who work in this centre, from the principal to the cleaners and kitchen staff". P17: (22:22), EDCO.

[...] if you mean the centre's human level of organisation then, obviously, when we have colleagues in our own organisation everything runs smoothly. We have colleagues that assume responsibilities, like, for 
instance, the course coordinators, who help a great deal in the performance of our duties. Why? I like the fact that everybody has a responsibility and that each member of the staff does whatever they are assigned to do. P3: (19:19), RSPN.

Finally, the interviewees mentioned the parents and the regulations (PARE, REG2, frequency $=2$, i.e. $10 \%$ of the sample), since they benefit from the mutual understanding with the parents, from the fact that every aspect is regulated and complies with the regulations, and from the approval of parents and teachers. "...one of the elements that make my job easier is regulations; thus, we will always make sure that we comply with them". P17: (22:22), REG2.

Regarding the difficulties category, the codes that were repeated the most were "parents" and "teachers" (PAR1, TEAC, frequency=5, i.e. 25 of the sample). With respect to parents, there are factors that hinder school management. These are determined by the continuous meetings, which require a lot of attention and information due to the lack of understanding and dissatisfaction of some parents about regulations. "[...] the lack of understanding of very few parents who don't comply with the regulations of the centre". P8: (21:21), PAR1; "[...] unhappy parents who complain". P19: (28:28), PAR1.

In this regard, the participants also found important to highlight the difficult interaction that some parents have with the teachers since, being the principal, one must intervene, and this eventually affects them: "... with families, parents, who in turn have issues with the teachers and, in the end, everything lands on you". P12: (25:25), PAR1.

The interviewees pointed out that the difficulties that they find with respect to teachers are due, fundamentally, to the opposition they show regarding changes, their lack of involvement and issues between co-workers:

$[\ldots]$ the problems that some teachers pose when changes are proposed; they oppose because of their fear to change. I consider them "energy vampires" because with their pessimism they suck the energy of those teachers who are motivated to introduce changes in the school". P7: (23:23), TEAC.

Regarding the difficulties between colleagues:

[...] difficulties such as issues between colleagues, although these have been very unusual; mainly members of the staff who misunderstood their tasks and performed them the wrong way, and my duty was to remind them how they had to do them. Fortunately, it was only very few cases of people who are no longer working in this school. P19: (27:27), TEAC. 
However, the participants consider that in the face of difficulties, one must be a good negotiator and create conditions that favour the good working environment of the centre.

[...] there are difficulties from every aspect; a different thing is to see, as a principal, how one experiences difficulties from each aspect. There are colleagues who get very upset because the city hall takes two weeks to send someone to plant a tree; it seems that their lives depend on that. There are other colleagues who are really affected by the difficulties of some students regarding discipline, etc.; other colleagues have a very bad time dealing with the difficulties they have with their co-workers. And then, there are some colleagues who are very upset with all kinds of difficulties. P12: (26:26), TEAC.

In this category, the participants also highlighted the relationships with students, the lack of experience and students themselves (REL1, LAEX, STUD, frequency $=3$, i.e. $15 \%$ ). With respect to relationships with students, they pointed out as a difficulty the discipline issues: "[...] basically, some case of discipline of the so-called "target" students, who are those that get constantly involved in everything and bother everyone". P17: (25:25), REL1. They also mentioned coexistence issues between students: "[...] then, we've had other types of difficulties affecting relationships between students themselves. There's always a conflict of coexistence". P3: (23:23), REL1.

Moreover, they considered the lack of experience as an additional type of difficulty that they had to solve by asking their colleagues: "...I learned by asking other colleagues who had been the school's principal in the past, but also from everyday experience; I mean, it's difficult, because a principal can find difficulties from any aspect". P14: (25:25), LAEX.

To sum up, as a school principal, the participants stated that there are difficulties from every aspect: "...there are difficulties with the students, when they show inappropriate behaviours, when they don't follow the levels required in each course". P12: (25:25), STUD; "...we have also had problems with certain students, but these were also very few cases because, in general, the coexistence climate in this centre is good. There had been some problems with former students with whom we went to court, but these were very few cases". P19: (27:27), sTUD.

However, the codes that repeated with the lowest frequency were: bureaucracy, regulatory changes and new projects (BURE, REG3, NEWP, frequency $=2$, i.e. $10 \%$ of the sample). In this regard, the interviewees mentioned that: "...fortunately, to this day, I haven't found many difficulties. To mention some, perhaps the deadlines we are given to hand in documents and fill in forms". P8: (21:21), BURE. 
In the management model category, the participants highlighted three codes: participative, representative and mixed. The most frequent code was participative (PART, frequency=17, i.e. $85 \%$ of the sample): "[...] Participative, without question" P1: (24:24), PART. "...As participative as possible and collaborative within the whole of the educational community" P10: (34:34), PART. "...I consider my school management model to be participative, since all the decisions of the faculty must reach consensus. We prioritise values such as participation and commitment by everybody". P7: (26:28), PART.

It is worth mentioning that the validity and reliability of the results presented in this section are guaranteed, at least partially, by the high consistency index obtained between the encoders (Altman, 1991). As is shown in Table 2, the rounded value of Cohen's Kappa is 0.87 . The probability of coincidence between encoders due to chance is discarded $(p=.000)$.

Table 2.

Consistency index between encoders (Cohen's Kappa)

Estimated Kappa, Asymptotic Standard Error,

and Test of Null Hypothesis of $O$ Population Value

\begin{tabular}{cccc}
\hline Kappa & ASE & Z-Value & P-Value \\
\hline .87787580 & .06424844 & 15.3758715 & $.000^{* * *}$ \\
\hline
\end{tabular}

${ }^{*} p<.05{ }^{* *} p<.01{ }^{* * *} p<.001$

Own source

Table 3 shows the words that were mentioned with the highest frequency by the 20 principals interviewed, as well as the number of letters that each consists of, their frequency of appearance and their percentage. The most frequent words were: centre, changes, management, team, regulations, parents, teachers and meetings.

Table 3.

Most mentioned words and their frequency, percentage and number of letters

\begin{tabular}{|c|c|c|c|}
\hline Words & Length & Total Count & $\%$ \\
\hline Activities & 11 & 55 & $0.20 \%$ \\
\hline Pupils & 8 & 22 & $0.08 \%$ \\
\hline Students & 7 & 71 & $0.26 \%$ \\
\hline Year & 3 & 33 & $0.12 \%$ \\
\hline
\end{tabular}




\begin{tabular}{|c|c|c|c|}
\hline Words & Length & Total Count & $\%$ \\
\hline Support & 5 & 26 & $0.09 \%$ \\
\hline Classroom & 4 & 26 & $0.09 \%$ \\
\hline Autonomy & 9 & 48 & $0.17 \%$ \\
\hline Changes & 7 & 85 & $0.31 \%$ \\
\hline Characteristics & 15 & 32 & $0.12 \%$ \\
\hline Centre & 13 & 384 & $1.39 \%$ \\
\hline Centres & 7 & 30 & $0.11 \%$ \\
\hline Season & 5 & 32 & $0.12 \%$ \\
\hline Faculty & 8 & 23 & $0.08 \%$ \\
\hline School & 7 & 39 & $0.14 \%$ \\
\hline Colleagues & 10 & 56 & $0.20 \%$ \\
\hline Advice & 7 & 22 & $0.08 \%$ \\
\hline Criteria & 9 & 42 & $0.15 \%$ \\
\hline Course & 5 & 45 & $0.16 \%$ \\
\hline Decisions & 10 & 24 & $0.09 \%$ \\
\hline Difficulties & 12 & 44 & $0.16 \%$ \\
\hline Management & 9 & 66 & $0.24 \%$ \\
\hline Managerial & 9 & 44 & $0.16 \%$ \\
\hline Principal & 8 & 55 & $0.20 \%$ \\
\hline Education & 9 & 48 & $0.17 \%$ \\
\hline Educational (female) & 9 & 21 & $0.08 \%$ \\
\hline Educational (plural) & 10 & 29 & $0.10 \%$ \\
\hline Educational (male) & 9 & 43 & $0.16 \%$ \\
\hline Realization & 11 & 42 & $0.15 \%$ \\
\hline Elements & 9 & 29 & $0.10 \%$ \\
\hline Interview & 10 & 32 & $0.12 \%$ \\
\hline Team & 6 & 87 & $0.31 \%$ \\
\hline Evaluation & 10 & 54 & $0.20 \%$ \\
\hline
\end{tabular}




\begin{tabular}{|c|c|c|c|}
\hline Words & Length & Total Count & $\%$ \\
\hline Facilitate & 9 & 23 & $0.08 \%$ \\
\hline Man & 6 & 22 & $0.08 \%$ \\
\hline Introducing & 13 & 35 & $0.13 \%$ \\
\hline Laws & 11 & 74 & $0.27 \%$ \\
\hline Improvement & 7 & 33 & $0.12 \%$ \\
\hline Model & 6 & 30 & $0.11 \%$ \\
\hline Needs & 11 & 38 & $0.14 \%$ \\
\hline Children & 5 & 43 & $0.16 \%$ \\
\hline Level & 5 & 57 & $0.21 \%$ \\
\hline Regulations & 9 & 30 & $0.11 \%$ \\
\hline Parents & 6 & 77 & $0.28 \%$ \\
\hline Participate & 10 & 31 & $0.11 \%$ \\
\hline Plan & 4 & 34 & $0.12 \%$ \\
\hline Practice & 8 & 39 & $0.14 \%$ \\
\hline Primary & 8 & 27 & $0.10 \%$ \\
\hline Main & 11 & 23 & $0.08 \%$ \\
\hline Problems & 9 & 37 & $0.13 \%$ \\
\hline Teacher & 8 & 21 & $0.08 \%$ \\
\hline Faculty & 11 & 41 & $0.15 \%$ \\
\hline Teachers & 10 & 53 & $0.19 \%$ \\
\hline Project & 8 & 32 & $0.12 \%$ \\
\hline Projects & 9 & 33 & $0.12 \%$ \\
\hline Resources & 8 & 36 & $0.13 \%$ \\
\hline Relationships & 10 & 40 & $0.14 \%$ \\
\hline Meetings & 9 & 59 & $0.21 \%$ \\
\hline ROO & 3 & 25 & $0.09 \%$ \\
\hline Translated & 9 & 33 & $0.12 \%$ \\
\hline Area & 4 & 35 & $0.13 \%$ \\
\hline
\end{tabular}


Lastly, Figure 1 shows the cloud of most repeated words.

Figure 1 presents the most representative words of the interviews conducted.

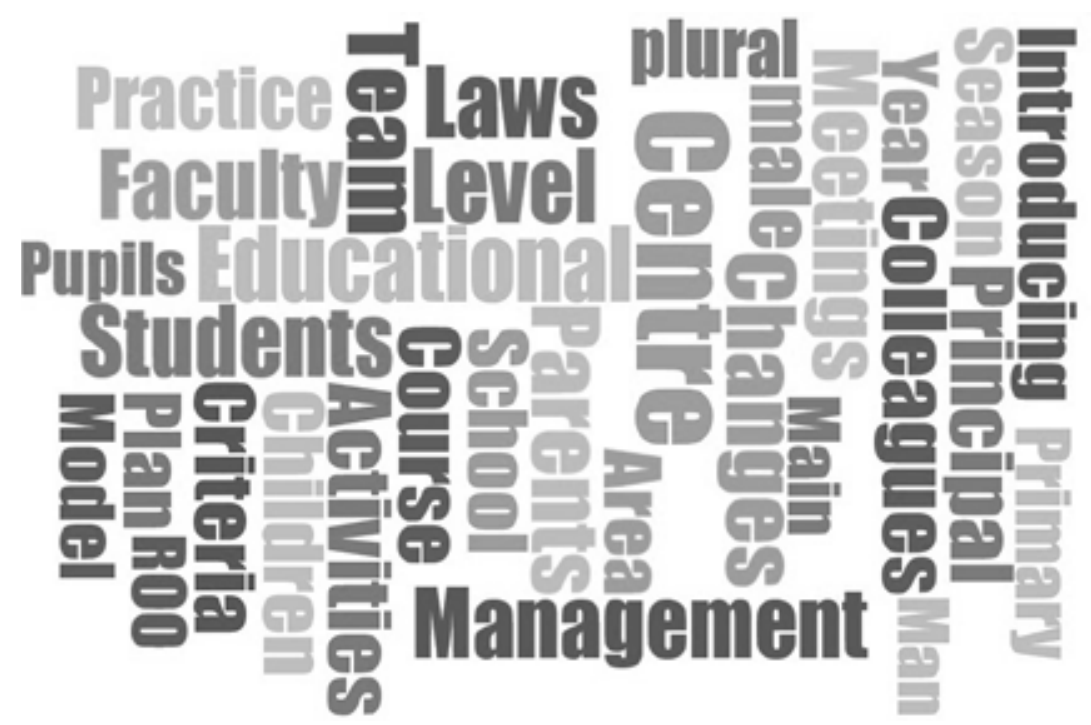

Figure 1. Word cloud

Own source

\section{Discussion}

The conclusions of interest drawn from the analysis of the categories that were established and related to the objectives of the study are presented as follows: first, we highlight the contribution of the school principals interviewed regarding the characteristics and challenges that influenced their decision to stand for the role. After the content analysis, it can be asserted that most of the participants took the position of school principal as a personal challenge, followed, with a lower percentage, by those who stated to have accepted the role after being proposed by either the former principal or by the educational administration, mainly the inspector. Others took the position either because the former principal retired, or their colleagues proposed them. It is inferred that, for most of them, the decision to become the school principal was associated with the willingness to face challenges. Therefore, we consider that pedagogical management should be essential among their challenges, to ensure quality and efficient management. Navareño (2016) pointed out that the essence of principalship lies in the ability to find always the best answer, and, to 
this end, a school principal must ensure that all the members of the staff work toward the same goals, in order to improve the teaching-learning process as a requirement of academic success for everyone.

Likewise, the competencies perceived by the participants to adequately perform the duties of a school principal were analysed. In this regard, the principals interviewed stated, mostly, the following: management, capacity to listen and empathy (as personal skills); authority, being able to delegate, knowing how the centre works and motivating others (as interpersonal skills), in that order. These results highlight the management and leadership skills, in line with Campo (2010). To a lower extent, they also consider the following: understanding their colleagues, developing social skills, innovation, being organised, patience, being able to negotiate and knowing the regulations. To sum up, the most developed competence is that of management, followed by personal skills (leadership), social skills and, lastly, knowing how the centre works and motivating others. The most valued competencies not only include those regarding technical skills and knowledge, but also those associated with interpersonal relationships, which supports the idea that the top priority of the management team is people, rather than papers and tasks (Murillo, 2006). Since management is considered the first competence developed by school principals, it can be inferred that these results are consistent with the Spanish school management model, which is based on more bureaucratic and administrative aspects, although they consider it insufficient for the achievement of more favourable pedagogical conditions. These data are in line with the studies performed by Barrios-Arós, Camarero-Figuerola, Tierno-García and Iranzo-García (2015), García and Poblete (2003), Caminero (2012) and Murillo (2006), which showed that most school principals consider that their model is mainly based on management, followed by decision-making and interpersonal relationships, with proper technical training.

With regard to the elements that facilitate and hinder the characteristic tasks of the management team, the interviewees highlighted, as facilitating factors, the following: first, the relationships with their colleagues and having a good management team composed by trustworthy people, followed by the support of the educational community and communication between the teachers. To a lesser extent, they stated that the educational administration, the planning documents, the parents and the regulations facilitate their daily duties.

On the other hand, they indicated the following as difficulties: those parents who do not get involved in the school and who do not comply with its rules, the opposition of some colleagues to changes, and discipline issues. These results suggest that parents, teachers and relationships within the centre are elements that influence positively, but also negatively, the performance of a school principal's duties. The participants of this study emphasised that 
the teachers, the parents and, in general, the members of the educational community, must all have the same concerns and interests in order to feel like they are part of the whole. In this regard, Izquierdo (2016), Navareño (2016) and Ritacco \& Bolivar (2016) state that, in order to achieve the goals proposed, it is essential to create the suitable conditions for everybody to find a purpose for their tasks and duties. The data from the PISA report indicate that students obtain better academic results when the principals have more responsibility and leadership skills (Montero, 2010, 2013).

However, we consider that the interviewed principals admit facing a series of difficulties in practice that require a greater management capacity and professional recognition to be able to act successfully.

In any case, according to the TALIS study (MECD, 2013a, p. 45), all principals must meet the requests and duties established by the political momentum and by the educational laws of each country or region, although, ultimately, all of them are focused on the management of human resources and materials, communication and interaction with the whole of the educational community, decision making based on evidence, and exercising the necessary educational leadership to help students complete their studies successfully.

Finally, through the management model category, the participants were proposed to define their own management models, and the one that was repeated with an astonishing percentage was the participative model. Almost all the principals interviewed in this study proposed that this is the most suitable model to apply, since they consider that participation must be regular in the different groups that are integrated in the organisation of the centre, for a suitable delimitation of the objectives and proper decision making, in both ascending and descending order.

\section{Limitations}

The present study allowed us to approach the reality of school management in practice, to determine aspects related to the characteristics and challenges that they consider when accepting the role, the competencies that they perceive as necessary for the performance of their duties, and the factors that facilitate and hinder their tasks, using a qualitative methodology. However, further research should combine quantitative and qualitative methodologies to expand and generalise the results obtained.

\section{Funding}

This work is part of a R\&D study funded by the Spanish Plan for Scientific and Technical Research and Innovation 2013-2016 (DIFOTICYD EDU2016 75232-P) and by the research group (GID) HUM-390, also known as 
"Educational Research Group: Technological and Qualitative Analysis of the Teaching-Learning Processes" (in Spanish: "Grupo de Investigación Didáctica: Análisis Tecnológico y Cualitativo de los Procesos de Enseñanza-Aprendizaje"), of the government of Andalusia (Spain).

\section{References}

Ainscow, M. \& West, M. (2008). Mejorar las escuelas urbanas. Liderazgo y colaboración. Madrid: Narcea.

Altman, D.G. (1991). Practical statistics for medical research. New York: Chapman and Hall.

Álvarez, M. (2006). La misma dirección para una nueva escuela. Organización y Gestión Educativa. Revista del Forum Europeo de administradores de la Educación (3), 30-35.

Barber, M., Chijioke, C. y Mourshed, M. (2010) How the world's most improved school system keep getting better. https://www.mckinsey. com/industries/social-sector/our-insights/how-the-worlds-most-improved-school-systems-keep-getting-better

Barrios, C., Iranzo, P. \& Tierno, J. (2013). Avances teórico-prácticos y legislativos en la profesionalización de la dirección escolar en España. El caso de Cataluña. Profesorado. Revista de currículum y formación del profesorado, (17), 371-387.

Barrios-Arós, C. H., Camarero-Figuerola, M., Tierno-García, J. M., \& Iranzo-García, P. (2015). Modelo y funciones de dirección escolar en España: El caso de Tarragona. Revista Iberoamericana de Educación, (67), 89-106.

Bernal, J. L. (2008). La formación de directivos en ejercicio. Revista de Educación, (348), 429-449.

Bolívar, A. (2010a). La autonomía de los centros educativos en España. CEE participación educativa, monográfico, 8-25.

Bolívar, A. (2010b). ¿Cómo un liderazgo pedagógico y distribuido mejora los logros académicos? revisión de la investigación y propuesta. Magis, Revista Internacional de Investigación en Educación, 3(5), 79-106.

Bolívar, A. (2015). Un liderazgo pedagógico en una comunidad que aprende. Padres y maestros, 361, 23-27. http://dx.doi.org/10.14422/ pym.i361.y2015.004

Caminero, J. M. (2012). Competencias de la dirección escolar para una gestión de calidad. [Tesis de grado, Escuela Universitaria de Educación de Palencia].

Campo, A. (2010). Herramientas para directivos escolares. Madrid: Wolters Kluwer. 
Day, C., Sammons, P., Leithwood, K., Hopkins, D., Qing, G., Brown, E. \& Ahtaridou, E. (2011). Successful school leadership linking with learning and achievement. England: Open University Press.

Estruch, J. (2002). Hacia la profesionalización de la dirección de centros escolares. Revista de Educación, 329, 77-90.

Gago, F. (2006). La dirección pedagógica en los institutos de enseñanza secundaria: un estudio sobre el liderazgo educacional. Madrid: CIDE, Ministerio de Educación.

Gairín, J. \& Castro, D. (2010). Situación actual de la dirección y gestión de los centros de enseñanza obligatoria en España. Revista Española de Pedagogía, 247, 401-416.

García, A. \& Poblete, M. (2003). Desarrollo profesional en la dirección de centros educativos, hacia la construcción de un modelo basado en competencias. En Congreso Internacional: Humanismo para el siglo Xxı. Bilbao: Universidad de Deusto.

Hallinger, P. \& Heck, R. (2011). Conceptual and methodological issues in studying school leadership effects as a reciprocal process. School Effectiveness Ans School Improvement, 22, 149-173. http://dx. doi.org/10.1080/09243453.2011.565777

Heck, R. \& Hallinger, P. (2010). Testing a longitudinal model of distributed leadership effects on school improvement. The Leadership Quarterly, 21, 867-885. https://doi.org/10.1016/j.leaqua.2010.07.013

Hernández, R.; Fernández, C.; Baptista, P. (2010). La metodología de la investigación ( $5^{\mathrm{a}}$ ed.). México: McGraw-Hill Interamericana.

Instituto Nacional de Evaluación Educativa (INEE). La calidad de los directores, 2013. http://www.mecd.gob.es/dctm/inee/boletines/boletin7. pdf?documentld=0901e72b815cfb21

Iranzo-García, P., Barrios-Arós., C. \& Tierno-García, J. (2008). Una experiencia para la mejora de la función directiva en centros inmersos en contextos de dificultad. Aula de Innovación Educativa, 171, 38-43.

Izquierdo, D. (2016). ¿Qué hacen los directores de centros escolares? las prácticas de dirección en España a partir de los estudios internacionales PISA y TALIS. Revista Complutense de Educación, 27(3), 1193-1209. http://dx.doi.org/10.5209/rev_RCED.2016.v27.n3.47610

Jefatura del Estado. (1985, 4 de julio). Ley Orgánica 8/1985. Ley Reguladora del Derecho a la Educación. Boletín Oficial del Estado BOE-A-1985-12978.

Jefatura del Estado. (2006, 4 de mayo). Ley Orgánica2/2006. Ley de Educación. Boletín Oficial del Estado BOE-A-2006-7899

Jefatura del Estado. (2013, 10 de diciembre). Ley Orgánica 8/2013. Ley para la Mejora de la Calidad Educativa. Boletín Oficial del Estado BOE-A-2013-12886. 
Leithwood, K., Patten, S. \& Jantzi, D. (2010). Testing a conception of how leadership influences student learning. Educational Administration Quarterly, 46, 671-706.

LOMCE. Ley para la Mejora de la Calidad Educativa. Ley Orgánica 8/2013, de 9 de diciembre de 2013, texto consolidado de 2018 (Publicado en boe el 23 de marzo).

Ministerio de Educación Cultura y Deporte. (2013). Estudio TAlis 2013. Estudio Internacional de la Enseñanza y el Aprendizaje. https:// www.educacionyfp.gob.es/dctm/inee/internacional/talis2013/talis2013 informeespanolweb.pdf?documentld=0901e72 b819e1729

Montero, A. (2010). El valor añadido de los centros. Un efecto necesario y "residual". Escuela, 3879, 39.

Montero, A. (2013). Dirección de centros y resultados educativos. Una relación mediada por el liderazgo. Revista del Fórum Europeo de Administraciones de la Educación, 6, 11-14.

Mulford, B. \& Silins, H. (2009). Revised models and conceptualization of successful school principalship in Tasmania. In Successful school principalship in Tasmania (pp. 157-183). Launceston, Tasmania: Faculty of education: University of Tasmania.

Murillo, F.J. (2006). Una dirección escolar para el cambio: del liderazgo transformacional al liderazgo distribuido. Revista Electrónica Iberoamericana sobre Calidad, Eficacia y Cambio en Educación, 4, 1124.

Navareño, P. (2016). La mejora del proceso enseñanza-aprendizaje como requisito imprescindible para el éxito escolar. Revista Electronica Forúm de Aragón, 17, 7-11.

Perines, H. \& Hidalgo, N. (2018). "La escuela confía en que los estudiantes podemos cambiar el mundo": un estudio de las escuelas que trabajan para la justicia social. Revista Colombiana de Educación, 75, 19-38.

Pont, B., Nusche, D. \& Moorman, H. (2009). Mejorar del liderazgo escolar. Volumen 1: política y práctica. OCDE.

Pont, E. \& Teixidó, M. (2002). El cambio planificado para la activación del rolo autónomo. En M. Teixidor (Ed.). Proyecto de formación para la implantación de cuidados en el marco del modelo conceptual de Virginia Henderson en los centros de atención primaria del Instituí Cátala de la Saint. Barcelona (pp. 65-94). Fundación-La Caixa.

Ritacco, M. y Bolivar, A. (2016). Impacto del modelo español de dirección escolar en la identidad profesional los líderes escolares. Archivos Analíticos de Políticas Educativas, 24(119). http://dx.doi. org/10.14507/epaa.24.2512

Sánchez-Moreno, M. \& Hernández, R. (2014). Otros tiempos, nuevas visiones de liderazgo educativo. REICE. Revista Iberoamericana Sobre

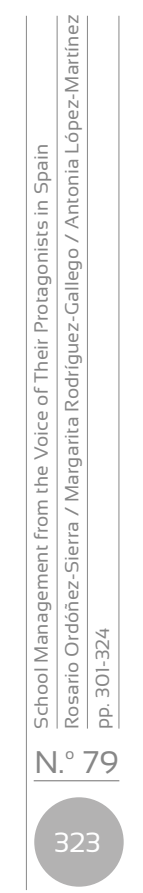


Calidad, Eficacia y Cambio en Educación, 12, 334-359.

Teixidó, J. (2007). Competencias para el ejercicio de la dirección escolar. XVIII Jornadas Estatales del Forum Europeo de Administradores de la Educación. http://www.joanteixido.org/doc/comp_direct/jornadas_ toledo.pdf

Vázquez, S., Liesa, M. \& Bernal, J. L. (2015). Análisis de la formación en liderazgo en organizaciones educativas: un estudio en la comunidad autónoma de Aragón. Revista Electrónica Interuniversitaria de Formación del Profesorado, 18(3), 39-54.

Viñao, A. (2016). El modelo neoconservador de gobernanza escolar. Principios, estrategias y consecuencias en España. En J. Collet y A. Tort, (eds.), La gobernanza escolar democrática (pp. 41-64). Madrid: Morata. 